\title{
Сфера компьютера и Интернета в русском языковом сознании (на примере глаголов компьютерного интерфейса)
}

\author{
А. Ф. КОЛЯСЕВА \\ Faculty of Arts, University of Leuven, Blijde Inkomststraat 21, office 217, B-3000 Leuven \\ E-mail: alyona.kolyaseva@gmail.com
}

(Received: 20 May 2015; accepted: 15 July 2015)

\begin{abstract}
Based on a semantic study of Russian verbs relating to computer interface, this paper explores structural metaphors of computer discourse organizing the perception of the computer and the Internet as well as forming its linguistic image. Four metaphors are discussed: 1. Computer is a special world; 2. Computer is a mechanism; 3. Computer is a book (library); 4. Computer is a living being. These metaphors are shown to function both independently and in interplay within the same text.
\end{abstract}

Keywords: Russian, linguistic image of the world, computer language, verbs, metaphors

Несмотря на то, что компьютер и Интернет сравнительно недавно появились в жизни рядового человека, сейчас это уже ее неотъемлемая часть, поэтому для лингвистического изучения лексика компьютерной сферы представляет несомненный интерес. Во-первых, это новый пласт русской лексики, еще недостаточно изученный. К тому же, по мере развития компьютерных технологий (а это одна из самых перспективных и быстро развивающихся отраслей знания) изменения происходят и в обслуживающей их лексике. Вовторых, не совсем ясен статус этой лексики, так как она может использоваться как специалистами, так и обычными пользователями. В-третьих, существует проблема перевода, поскольку изначально лексика компьютерной сферы создается вместе с новым компьютерным продуктом или технологией и не на русском языке. Список нерешенных вопросов можно продолжать.

В настоящей статье я не буду останавливаться на проблемах пополнения терминологического фонда (о проблеме перевода терминов компьютерной сферы см. КолясевА 2009), но проанализирую функционирование лексики, уже закрепившейся в языке, а именно лексики, с которой сталкивается рядовой пользователь в процессе «общения» с компьютером. Пользовательский интерфейс создается специалистами в том числе и для неспециалистов, а значит, становится полем взаимодействия обыденного и профессионального языкового сознания. В большинстве случаев это лексико-семантические кальки с английского языка, но для целей настоящего исследования это не столь важно. Поскольку компьютерные технологии достаточно прочно внедрились в жизнь человека и его сознание (в том числе языковое), представляется воз- 
можным рассматривать успешно функционирующую лексику этой сферы независимо от ее происхождения, обращая основное внимание на ее внутреннюю форму.

Интерес к внутренней форме лексемы обусловлен целью вскрыть основные метафоры рассматриваемого дискурса - «структурные метафоры» в терминологии Дж. Лакоффа и М. Джонсона (см. ЛАкОФФ-Джонсон 2008). В своем исследовании я отталкиваюсь от выдвинутого Дж. Лакоффом и М. Джонсоном положения о метафоричности человеческого мышления и попытаюсь проиллюстрировать метафорический когнитивный механизм, проанализировав семантику глаголов, используемых в пользовательском интерфейсе и в целом в дискурсе, обусловленном ситуацией «человек - компьютер». Данная задача является частью вопроса о том, как представлена сфера компьютера и Интернета в русском языковом сознании.

Поскольку метафора является не только средством языковой выразительности, но и средством представления информации и инструментом познания, метафоры компьютерного интерфейса привлекают пристальное внимание не только лингвистов, но и философов, логиков, психологов, когнитивистов и самих специалистов компьютерной сферы (см., например, АвЕРБух и др. 2007, ЛожкИна 2001, ГАЛКИна 2004, JoHnson 1994, BARвosA-SOUZA 2000, BARRNoBle-BIDdLe 2004). Разработчиков компьютерного интерфейса метафора интересует, главным образом, с точки зрения ее удачности в целях визуализации: метафора рабочего стола, метафора комнаты, метафора картотеки, молекулы, ландшафта (АвЕРБух и др. 2007, АвЕРБух и др. 2008, ИСмАГИловШАРПАН 2003 и др.). Меня интересует прежде всего языковой образ. Специалисты придумывают и реализовывают метафоры для облегчения диалога между пользователем и компьютером, соответствующим образом выстраивая интерфейс и привлекая при этом лексику, поддерживающую ту или иную метафору. Пользователь эту метафору воспринимает, и в его сознании формируется языковой образ компьютера и всего, что с ним связано, не обязательно в точности совпадающий с исходной метафорой разработчиков программ.

В процессе предпринятого анализа глагольной лексики исследуемой сферы были выявлены следующие метафоры: 1) компьютер - это отдельный мир; 2) компьютер - это механизм; 3) компьютер - это книга; 4) компьютер - это живое существо. Эти метафоры определенным образом организуют языковое сознание пользователей в той его части, которая касается взаимодействия с компьютером. Следующие параграфы посвящены подробному освещению этих метафор.

\section{1. Компьютер - это отдельный мир}

Словосочетанием виртуальная реальность, понимаемым как «реальность, отличная от действительного, материального мира, основой которой будут являться нематериальные понятия - информация, мысли и образы» (РЕпкин 1999-2009), теперь никого не удивишь. В большинстве случаев под 
виртуальной реальностью понимается именно реальность, создаваемая компьютером, в частности, Интернетом. «Сам Интернет - то самое виртуальное пространство, пространство чистой информации и пространство общения. Часть этой информации действительно соответствует существованию объектов в реальном мире, но часть является чисто абстрактной. Сами компьютерные технологии являются абстрактными в принципе - многие из них предназначены лишь для того, чтобы являться основой преобразования одного вида абстрактных данных в другой. Общение в сети Интернет приводит к созданию виртуальных сообществ, которые создаются вокруг различных тематик и служат решению различных вопросов» (РЕпкин 1999-2009).

Вопросы виртуальной реальности, ее возможностей и ее безопасности для психики человека, активно обсуждаются. Моя цель - рассмотреть, как понятие виртуальной реальности отразилось в языке.

Анализ лексики, обслуживающей компьютерную сферу, показывает, что и в языке компьютер представлен как отдельный мир со своим пространством и временем, а главное - со своими законами, где человек может быть творцом. Стоит только вспомнить, как часто на экране появляется глагол создаmb. Coздать можно папку, портфель, архив, ярльк, файл, документ, странииу, груп$n y$, даже событие и т. д. Последнее сочетание воплощает идею Г. Маклюэна о том, что новые средства коммуникации оказывают влияние на человеческое общение (впрочем, аналогичную идею можно увидеть и в мысли В. Гюго о книгопечатании: «книга убьет здание»). Так, с появлением мобильных телефонов, одним из распространенных вопросов стал вопрос о местонахождении собеседника, который до этого был в большинстве случаев немыслимым из-за стационарности телефонного аппарата. Многократно обсуждалось словосочетание «добавить в друзья», возникшее с развитием социальных сетей. Таким образом, нельзя обойти молчанием тот факт, что и Интернет, как новое средство коммуникации, активно воздействует на наш язык.

В «Словаре русского языка» под ред. А. П. Евгеньевой (МАС) выделено четыре значения слова создать (толкования приводятся с сокращениями):

\section{Создать}

1. Путем творческих усилий и труда дать существование чему-л., вызвать к жизни что-л. Создать научную теорию. Создать симфонию. Создать поэму. $\|$ Построить, возвести. «Шпитцер любил Вену как город, созданный его дедами и прадедами» (Павленко: Труженики мира);

2. Основать, организовать. Создать армию. Создать оркестр. || Образовать, сформировать. Создать спортивные группь;

3. Обеспечить что-л. «Слова эти запомнились женщинам слободы, они создали кривому славу человека справедливого» (М. Горький: Городок Окуров). ॥ Вызвать появление чего-л., стать причиной чего-л. Создать затруднения;

4. Определить в основных чертах, свойствах. «Человек так создан, что для него жизнь иначе невозможна, как жизнь в обществе» (Станкевич: Письмо Я. М. Неверову, 21 сент. 1836 г.). || [обычно в форме прич. страд. прош.] Быть предназначенным для чего-л. в силу своих особенностей, свойств. «Тарас был один 
из числа коренных, старых полковников: весь был он создан для бранной тревоги» (Гоголь: Тарас Бульба).

В компьютерном создать на первый план выходит прежде всего значение 'дать существование чему-либо, вызвать к жизни что-либо', потому что создать можно не что-то качественно новое, а по сути всего лишь выбрать объект создания из предложенных вариантов. Элемент творческого акта, активности, таким образом, уходит на второй план, но, тем не менее, не исчезает во многом благодаря внутренней форме слова и существует на уровне коннотаций. В общем же виде это значение можно представить как «Х каузирует возникновение Y в мире (реальности) Z». Под миром (реальностью) $\mathrm{Z}$ здесь понимается «компьютерный» мир или более узко - конкретное виртуальное пространство (папка, портфель и т. д.). Эту валентность необходимо отметить, поскольку ничего материального при нажатии кнопки «создать» в реальном мире не возникает и для перевода объекта в этот реальный мир необходимы другие команды, такие как распечатать и т. д.

О метафоре пространства можно говорить и в связи с достаточно многочисленными пространственными глаголами, такими как: перейти на другую страницу (по ссылке), найти (искать, поиск), переместить, отправить какойлибо объект, информация может быть вывешена в Интернете или выложена в нем. Объем статьи не позволяет выписать все значения этих глаголов, указанные в словаре, поэтому по возможности ограничимся теми, которые наиболее соответствуют их узусу в дискурсе компьютерной сферы.

Найти

1. В результате поисков обнаружить; отыскать. «У него сделали обыск и нашли деньги в необычном месте, в валенке под печкой» (Чехов: Убийство); «После целого дня безуспешных поисков я нашел их, наконец, - в полотняной палатке одного из медсанбатов» (Б. Полевой: Братья Волковы); «[Глеб] обшарил комнату, но не нашел съестного» (Саянов: Небо и земля).

Несмотря на то, что в толковании слова как таковом не указана валентность на место, приведенные примеры показывают, что искать и найти объект поисков необходимо в неком пространстве - «у него», «в необычном месте, в валенке под печкой», в палатке, в комнате. Следовательно, употребление глагола найти в компьютерном дискурсе в отношении локализации не привносит в значение этого слова новых семантических элементов. В «компьютерном» мире поиски также ведутся в определенном пространстве - в сети Интернет, на странице, в документе, в самом компьютере как виртуальном пространстве. При этом поиски могут осуществляться человеком, как, например, при поиске в Интернете, когда необходимо самостоятельно просматривать предложенные страницы: Мне удалось найти в Интернете нужный материал для доклада. В этом случае значение слова можно представить как «X успешно завершил поиск Y в пространстве Z». По-другому будет построена схема, если глагол найти понимается как команда - субъектом поисков 
уже будет не человек X, а некая программа. Эта схема принимает следующий вид: «Х каузирует выполнение программы Q с целью поиска Ү в пространстве Z».

\section{Вывесить}

1. Повесить наружу, расположить в висячем положении. Вывесить флаги. Вывесить белье. Вывесить зимнюю одежду.

2. Поместить, повесить для обозрения, для всеобщего сведения. Bывесить объявление. Вывесить списки. Вывесить приказ. «Когда, наконец, воспитанников института распустили на экзамены, вывесили расписание и роздали программу билетов - началась зубрежка» (Скиталец: Кандалы).

Из двух указанных в МАС значений наиболее подходит для интересующего нас употребления второе. Значение можно определить как «Х размещает информацию Y в пространстве Z». Пространственная метафора очевидна из-за внутренней формы слова - вешать можно на что-либо, висеть можно на чем-либо или где-либо. Файлы вывешиваются в Интернете (внутри виртуального пространства), на странице, стене и т. д. (на виртуальной плоскости, которая благодаря внутренней форме слова мыслится как вертикальная).

\section{Выложить}

1. Положить наружу, вынув откуда-л. Выложить вещзи из чемодана. «Вспомнив, что у него документы и оружие Филипчука, Сабуров выложил все на стол» (Симонов: Дни и ночи).

2. перен. разг. Высказать, сообщить все. «[Лунев] сбивчиво говорил и двоился между желанием рассказать историю Маши и выложить перед девушкой свои мысли по поводу этой истории» (М. Горький: Трое); «Николай и слова не промолвил, пока Быков не выложил ему все свои сомнения и раздумья» (Саянов: Небо и земля).

3. чем. Покрыть какую-л. поверхность, укладывая что-л. на ней; выстлать. «Есть места на городских улицах, выложенные камнями...» (Бунин: Суходол); «Пол выложен цветными плитками, шахматной мозаикой» (Гладков: Цемент). || Уложить по поверхности или вставить, врезать что-л. в виде узора, надписи и т. п. «На крышке ее [шкатулки] медными буквами была выложена английская надпись» (Паустовский: Жильцы старого дома). || Устар. Нашить на ткань для украшения. «За князем - двигалось княжеское семейство. В кружевах и атласе, в старинной, галунами выложенной одежде выплывала - жена князя» (Либединский: Горы и люди).

4. Сложить, соорудить из камня, кирпича и т. п. «Моя печь стояла готовая; в ней была выложена кладка из превосходного огнеупора» (М. Павлов: Воспоминания металлурга); «Когда его зовут выложить печку, он никак не может назначить цену за работу» (Паустовский: Записки Ивана Малявина).

Из всех указанных в МАС значений интересующему нас употреблению не соответствует ни одно. Значение совпадает со значением компьютерного вывесить: «Х размещает информацию Y в пространстве Z», но при этом пространство мыслится не как вертикальное, а как горизонтальное. 


\section{Перейти}

2. Переместиться из одного места в другое. Перейти в другую комнату. Перейти от окна к столу. «[Капитан парохода] перешел на правый мостик» (Катаев: Белеет парус одинокий).

\section{Переместить}

1. Передвинуть, переставить с одного места на другое, изменить местоположение чего-л. «[Реутов] приказал денщику, переместив мебель, поставить на место умывальника платяной шкаф» (Кремлев: Большевики); «Памятник хотели переместить поближе к новым районам» (Атаров: Магистральная горка).

Эти глаголы наиболее очевидно раскрывают пространственную метафоpу: актанты начальной и конечной точки представляют собой не что иное, как пространственные координаты, среди которых происходит движение. О метафоре движения писал, в частности, Р. Лейбов в статье «Язык рисует Интернет»: «Разные метафоры живут в разных стилях. В „высоком слоге“ мы говорим что-нибудь вроде путешествие по бескрайним просторам Интернета (уже не помню, где я в последний раз видел эту фразу). В веб-обозрениях чаще встречается термин бродить (особенно любил его, конечно же, обозреватель, скрывавшийся под соответствующим псевдонимом - Сетевой Странник). В разговоре то же действие обозначается еще более сниженным глаголом - лазать. Заметим, что все эти обозначения - метафоры движения, но конструируют они принципиально разные картины» (ЛЕйБов 1997).

Все эти глаголы - nутешествовать, бродить, лазать - предполагают наличие пространства, внутри которого происходит передвижение, и некой плоскости, по которой оно осуществляется. Другими проявлениями «метафоры пространства» помимо указанных выше глаголов являются сочетания зайти /войти в Интернет, на сайт, на форум, в почту и т. п. и выйти/уйти из Интернета, с сайта, с форума, из почты и т. п., а также быть, работать и сидеть в Интернете, сидеть на форуме, Вконтакте и под.

Значение глагола зайти трансформировалось. Его значение идентично значению глагола войти. В МАС отмечены следующие значения зайти (приводятся с сокращениями):

\section{Зайти}

1. Идя, по пути побывать где-л., посетить кого-л., что-л., наведаться к кому-л., куда-л. «Марья Константиновна остановилась около своих ворот и пригласила ее зайти посидеть» (Чехов: Дуэль). \| за кем-чем. Прийти куда-л., чтобы взять с собой кого-л., что-л. «[Наташа:] Я за часами зайду. Или, знаете что, занесите их бабушке» (Розов: Страница жизни); «Нынче в самом конце рабочего дня Маринка зашла за мной» (Шуртаков: Возвратная любовь). \| во что. Войти, проникнуть куда-л. «В деревню я зашел не с того ее конца, который был обращен в сторону Глотовки, а с противоположного» (Исаковский: На Ельнинской земле);

2. Уйти далеко, в какие-л., за какие-л. пределы или, идя, попасть не туда, куда следует. «Казалось, как ясно должно было быть для Наполеона, что, зайдя за две тысячи верст и принимая сражение с вероятною случайностью потери 
четверти армии, он шел на верную погибель» (Л. Толстой: Война и мир). || перен. Перейти какую-л. грань, меру. «[Ознобишин] сладеньким тенорком сказал Лизе - «ты». Вон куда зашло!» (Федин: Необыкновенное лето);

3. Подойти к чему-л. не прямо, а со стороны, обходя. «Я зашел с другой стороны коляски и ждал своей очереди садиться» (Достоевский: Село Степанчиково);

4. Идя, двигаясь, оказаться позади чего-л. или скрыться за чем-л. «[Марья Дмитриевна] встала и, проворно зайдя за ширмы, вывела оттуда Варвару Павловну» (Тургенев: Дворянское гнездо);

5. Опуститься за горизонт, закатиться (о небесных светилах);

6. Возникнуть, начаться (о разговоре, споре и т. п.). «Недавно спор зашел о дамах высшего круга» (Пушкин: Роман в письмах).

Если исключить пятое значение как абсолютно неподходящее, то можно сказать, что в целом для значений этого слова характерен элемент случайности, непреднамеренности, который, тем не менее, в словосочетании зайти в Интернет полностью исчезает, так как действие представляется как осмысленное - мы не заходим в Интернет по пути, невзначай. Единственное подходящее значение - «войти, проникнуть куда-либо». Интересно, что в наиболее подходящем толковании глагола войти тоже присутствует проникнуть:

\section{Войти}

1. Идя, двигаясь, проникнуть куда-л., в пределы чего-л. Войти в комнату. Войти в воду. «За ночь в станицу вошли крупные силы казаков» (А. Н. Толстой: Хмурое утро); Mы вошли в бухту, и такой же, как это утро, бельй, розовый, снежный городок открылся передо мной (Каверин: Два капитана). || Проникнуть вглубь, внутрь чего-л. Заноза вошла глубоко внутрь. Лопата вошла в землю. «Осколок мины вошел ему в плечо» (Николаева: Гибель командарма).

Итак, у пространства Z есть свои границы. Войти или зайти в Интернет значит «X проникает в пределы пространства Z».

В отношении функционирования глагола выйти можно говорить об энантиосемии: в словосочетаниях выйти в Интернет и выйти из Интернета он употребляется в противоположных значениях. В первом случае глагол является синонимом слов зайти и войти («Х проникает в пределы пространства Z»). Во втором - значение обратное: «X покидает пределы пространства Z». Оба значения не являются новыми для русского языка (рассматриваемые сочетания аналогичны словосочетаниям выйти в сад и выйти из сада) и так или иначе представлены в МАС:

\section{Выйти}

1. Уйти откуда-л., оставить пределы чего-л. Выйти из дому. Войска вышли из города. Выйти из машины. \| перен. Покинуть что-л., прекратить свое пребывание где-л. Выйти из госпиталя. «Я жил тогда в Петербурге - и только что вылиел из университета» (Тургенев: Стук... стук... стук!); «[Сева:] Ведь он же сам тысячу раз тебе говорил, сам, сам, сам вышел из бригады» (Погодин: Цветы живые); 
2. Прийти куда-л., оказаться где-л.; появиться, показаться. «Но вот она [Ермолова] вылила на сцену и начала монолог» (Юрьев: Записки). || В сочетании с некоторыми существительными означает: отправиться с какой-л. целью (обозначенной существительным). Выйти на прогулку. Выйти на охоту. Выйти на добычу.

Рассматриваемые сочетания выйти в Интернет и выйти из Интернета в этих значениях аналогичны словосочетаниям выйти в сад и выйти из сада. Помимо этого в словосочетании выйти в Интернет есть элемент значения «получить доступ к чему-либо» (близкое к этому значение содержится в сочетании выйти на международный рынок). Также можно добавить, что слово выйти не привязано к семантическому полю Интернета: оно успешно функционирует в словосочетаниях выйти из программы, выйти из игры и т. д.

Что касается словосочетаний быть, работать, сидеть в Интернете, пространственная метафора представляется в данном случае явной, поэтому нет необходимости в ее комментировании. Заметим только, что эти глаголы предполагают длительное нахождение в пределах «пространства Z».

Таким образом, в языке компьютер и Интернет представлены как обособленный мир, где есть свое пространство в горизонтальном (выложить, nутешествовать, бродить) и вертикальном (вьвесить, лазать) измерениях, настолько большое, что в нем можно потеряться или что-либо потерять (най$m u)$, где есть свои границы (выйти, войти, зайти), свои правила (достаточно вспомнить, как часто на глаза попадается слово зарегистрироваться) и свои возможности (например, купить что-нибудь) и где даже есть своя свалка корзина, которую необходимо время от времени очищать (глагол очистить). Здесь так же существует время (глагол подождите и все глаголы, предполагающие длительное действие). Субъектом действий в метафоре отдельного мира чаще всего выступает человек, но его статус в этом мире может быть различным. На одном полюсе стоит человек-творец, хозяин положения, агенс, осуществляющий действия или дающий команды; на другом - пациенс (в инволюнтивных сочетаниях типа выбросило из Сети).

Интересны наблюдения Р. Лейбова по поводу представления пространства и места в нем человека: метафора путешествия «живописует нам открытое пространство, едва ли не подобие развалившейся Империи. [...] Так и видишь этакого респектабельного англичанина викторианской эпохи (а может быть, просвещенного русского дворянина или японца с видеокамерой), оснащенного записной книжкой и путеводителем от г-на Житинского, неспешно передвигающегося, ночующего в солидных отелях, внимательно вглядывающегося в достопримечательности и дивящегося красотам природы и искусства на бескрайних, как и было сказано, просторах. „Бродить“ - не ,путешествовать“, странник или бродяга - совсем другой персонаж, он тащится (от Интернета) с сумой на плечах, никто нигде не ждет его. Его передвижение в пространстве лишено целенаправленности. [...] Представления, заложенные в метафоре „лазанья“, резко переключают метафорический регистр. Несомненно, 
речь здесь не идет о деревьях. Скорее, представляется нечто вроде знаменитых московских канализаций. Так или иначе, этот короткий глагол подразумевает представления о затрудненном и возможно направленном по вертикальной оси передвижении. Подобно персонажу Гиляровского или толкиенскому Хоббиту, наш бродяга отправляется в загадочный и мрачный подземный мир [...] Наконец, наше взаимодействие с Сетью может и вовсе описываться как неподвижность. В Интернет залезают, а потом в нем сидят (я уж не говорю о другой метафоре - когда сидят на Интернете). Канализационный люк захлопнулся над твоей головой. Попалась птичка, стой, не уйдешь из Сети» (ЛЕйБов 1997).

Несомненно, стоят внимания и наблюдения Р. Лейбова о распределении метафоры пространства и резервуара: «первую чаще употребляют активные пользователи, последнюю - их несчастные родственники и знакомые. „Изнутри“ Интернет видится пространством, в котором можно двигаться, „извне“как некоторый резервуар, в который бегут от жизни (вариант последней метафоры - „висеть в Интернете“ - демонстрирует неслучайность образа паутины)» (ЛЕЙБОВ 1997).

Так как компьютерный мир отличен от реального, в нем есть свои возможности, например, обратить время. Так, удаленный файл можно восстановить и получить абсолютно идентичный (в реальном мире идентичность вообще наблюдается редко, а процессы удаления, стирания, как правило, необратимы). В этом мире объекты легко трансформируются - ярче всего об этом свидетельствует глагол сохранить как. Интерес представляют глаголы nечатать, pacneчатать, сохранить: выясняется, что при печатании «в файл» никакого материального объекта не возникает, результат закрепляется только при выполнении команды сохранить, при этом с языковой точки зрения совершенно не ясно, где до этого существует результат работы и существует ли вообще. Также меняется значение слова удалить: действие оказывается неокончательным и обратимым. Зафиксированное в МАС второе значение глагола удалить 'убрать, вынести, вывести и т. п. что-л. лишнее, ненужное, мешавшее' могло бы поддерживать метафору пространства, но применимо не во всех случаях. В удалении файла можно действительно видеть его перемещение в другое пространство в силу его ненужности в пространстве Z, в том, в котором находится пользователь. Этот файл при необходимости можно перенести обратно в пространство Z - восстановить. Однако такое толкование неприменимо в команде удалить программу, удалить вирус в этом случае глагол имеет значение 'устранить'.

\section{2. Компьютер - это механизм}

Наряду с метафорой, представляющей компьютер как объемный мир, внутри которого находится человек, в языке компьютер также представлен как механизм, внешний по отношению к человеку. Во многом на этой метафоре построен командный принцип «общения» человека с компьютером, когда 
нажимается определенная клавиша-команда и запускается нужный процесс. Например, файл можно загрузить, скачать, архивировать, сжать, программу установить, настроить и запустить, Интернет подключить и отключить, программное обеспечение можно поменять, наконец, сам компьютер можно включить и выключить, на нем можно работать, он может сломаться и его можно отремонтировать или починить.

Если сам компьютер действительно является сложным механизмом и вполне логично его включать и выключать, то программа, файл и даже операционная система таковыми не являются, представляя собой, по крайней мере для неспециалиста, нечто нематериальное. В то же время в языке они закреплены именно как материальные детали механизма или целый механизм (ср. диспетчер устройств, панель инструментов):

\section{Установить}

2. Поставить, поместить где-л. механизм, приспособление и т. п., налаживая, подключая к чему-л., подготавливая к использованию. Установить турбину. Установить новую аппаратуру. Установить компьютер. Установить телефон. $\square$ Бригада Первухина, выйдя на смену, быстро сняла сработанные валки на стане и установила новые (В. Попов: Закипела сталь). || Привести механизм, машину в нужное положение, состояние. Bbl гораздо точнее установите ваши часы по хронометру главного штаба (Чернышевский: Очерки из политической экономии [по Миллю]). Ершов с прищепщиком заправили баки, запустили мотор, установили плуг на нужную глубину (Овечкин: Районные будни).

\section{Настроить $^{2}$}

2. Привести в состояние, нужное для работы, наладить, отрегулировать (станок, механизм и т. п.). Настроить станки. Настроить механизмы. $\square$ Голубев сел за микроскоп и долго не мог «настроить» его по своим глазам (Дягилев: Доктор Голубев)

\section{Запустить}

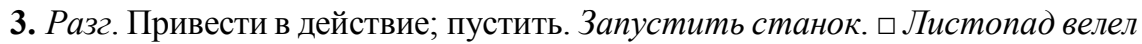
запустить мотопилу, чтобы мать посмотрела, как она работает (Панова: Кружилиха). Техник и Коробочкин поворотами винта запустили мотор. Он заработал четко и сильно (Шолохов-Синявский: Волгины).

Компьютер может сломаться, операционная система полететь. Оба глагола имеют одно значение и частотно употребляются в тех ситуациях, где речь идет о каком-либо механизме, а также предполагают при таком употреблении физическое повреждение:

\section{Ломаться}

1. Сгибаясь, перегибаясь или ударяясь с силой, разделяться, распадаться на части, куски. Сучья ломались, скрипели, трещали, Жалобно листья шумели кругом (Н. Некрасов: Саша). Нос ледокола въезжает на лед, и под его тяжестью ломаются и крошатся льдины.... (Соколов-Микитов: На белой земле). || Легко поддаваться ломке, быть ломким, хрупким. - А шпага наша потому гнется, не 
ломается, что калим ее до малинового ивета и закаливаем в конопляном масле (А. Н. Толстой: Петр Первый). \| Приходить в негодность, портиться. Старая телега, на которой я возил навоз, давно сгнила и ломалась уже несколько раз (Э. Грин: Ветер с юга).

\section{Полететь}

4. Сломаться, испортиться. Прошлой зимой на бетонном заводе два компрессора полетели. То есть сломались... (Зверев: Очкарик). Замучил этот мотор. Все время ждешь: винт ударит о камень, полетит шпонка, надо будет чинить. Шионка летела раз восемь (Песков: Край света).

\section{3. Компьютер - это книга (библиотека)}

Компьютер во многом занял место традиционной печатной книги. Нет больше надобности брать в библиотеке кипы книг, если в Интернете можно найти компактные электронные издания, доступ к которым можно получить, не выходя из дома. Сам Интернет представляет собой огромный архив материалов - от кратких новостных сводок до серьезных аналитических работ.

Чем дальше, тем более верным представляется мнение, которое высказал У. Эко в своей лекции на экономическом факультете МГУ 20 мая 1998 г. «От Интернета к Гутенбергу: текст и гипертекст» в противовес типичному взгляду на конкуренцию и смену средств коммуникации с точки зрения «Это убьет то»: «Безусловно, компьютер - орудие для производства и переработки образов, и так же безусловно, что инструкция нам дается в образе неизбежной иконки. Но так же известно, что старые компьютеры рождались как орудие письменности. По экрану ползли слова и строки, и пользователь должен был читать. Новое поколение детей из-за компьютера научилось читать с дикой скоростью, и сейчас тинэйджер читает быстрее, чем профессор университета - вернее, профессор читает медленнее, чем тинэйджер. Тинэйджеры, если они хоть что-то на своем компьютере программируют, должны знать логические процедуры и алгоритмы и должны печатать слова и цифры, причем очень быстро. В этом смысле компьютер возвращает людей в гуттенбергову галактику, и те, кто пасутся ночами в Интернете и болтают в чатах, они работают словами. Если телеэкран - это окно в мир, явленный в образах, то дисплей - это идеальная книга, где мир выражен в словах и разделен на страницы» (Эко 1998).

Неудивительно, что веками складывавшееся представление о книге как источнике знания переходит теперь на Интернет. В нем - те же страницы, которые можно читать, пролистать, есть электронные издания, журналь, каталоги; так же, как в обычной книге, можно использовать закладку, но ее придется создать.

Метафора книги распространяется не только на Интернет, но и на весь компьютерный мир. Для создания и пополнения «библиотеки» компьютер располагает графическими или текстовыми редакторами. Здесь она может трансформироваться в метафору рабочего стола с документами. Любой файл 
мы можем открыть/закрыть, редактировать, архивировать, просмотреть, nрочитать. Аналогична наведению порядка на письменном столе функция упорядочить значки.

Глагола архивировать (заархивировать) в МАС нет. Как бы то ни было, значение слов архив, архивный в русском языковом сознании связано с хранением письменных документов, следовательно, этот глагол входит в семантическое поле книги (документа). Однако в применении к компьютеру меняется значение самого слова архив - как и в реальном мире, архив создается для хранения информации, но хранения компактного. Архивирование становится синонимом сжатия файлов. Так, согласно «Большой компьютерной энциклопедии», архиватор - это «программа, выполняющая архивирование (сжатие) файлов для того, чтобы уменьшить их размер, что позволит более компактно разместить их на носителе информации, и разархивирование (восстановление сжатых файлов в первоначальном виде)» (ДуьЕнюк 2007: 18). Поскольку в мире Z процессы обратимы, появляется новый глагол - разархивировать.

\section{4. Компьютер - это живое существо}

Компьютер может восприниматься как механизм, облегчающий работу человека, но может представать и как живое существо, выполняющее его команды. Как живое существо, он не застрахован от болезней (как ни странно, инфекционных, для заражения которыми необходим контакт компьютеровсуществ) - в таких случаях мы говорим, что компьютер заражен вирусом, ${ }^{1}$ который, впрочем, можно вылечить (при этом в аналогичной ситуации будут употребляться слова другого семантического поля - сломаться/oтремонтировать, поддерживающие метафору механизма).

О представлении компьютера как о живом существе говорит обширный класс глаголов мысли (сочетания типа компьютер думает). Эта метафора заложена уже в самом термине «искусственный интеллект». Объяснение такого подхода к компьютеру можно найти в словах Дж. МакКарти, который считается автором термина: «Приписывать определенные „мнения“, ,знания“, „свободу воли“, „намерения“, „сознательность“, „способности“ или „желания“ машине или компьютерной программе - дело вполне законное, если такое приписывание выражает относительно машины ту же информацию,

\footnotetext{
${ }^{1}$ Компьютерный вирус - программа, состоящая из кодов и инструкций, которые постоянно выполняются (ДуБЕнЮк 2007: 53). Очевидно, что источником номинации является вирус в биологическом понимании - «неклеточный организм с геномом ДНК или РНК, способный к воспроизведению только в клетках более высокоорганизованных существ» (Ривкин 2010: 36). При этом интересно, что компьютерный вирус имеет тело, в отличие от вируса биологического (неклеточного организма). Следует иметь в виду, что значение лексемы тело в компьютерном дискурсе (для профессионалов) изменено, ср.: тело функции, тело цикла, тело процедуры. Обыденное же сознание, прочитав на экране о «теле вируса» представит не часть кода, а нечто более материальное.
} 
какую оно выражает относительно человеческой личности. Такое приписывание полезно, если оно помогает нам понять структуру машины, ее прошлое или будущее поведение или же облегчает ее исправление либо усовершенствование» (МсСАRTнY 1979: 161).

В этом ключе Э. МакКормак рассматривает компьютерную метафору ${ }^{2}$ как двунаправленную: компьютер видится как человек, а человек - как компьютер: «мозг может рассматриваться как вычислительный механизм, сходный с компьютером, а разум представляет собой ряд программ, обеспечивающих функционирование мозга» (МАККормАК 1990: 367). «Мы говорим о нейронных состояниях мозга, как если бы они были подобны внутренним состояниям компьютера; мы говорим о моментальных процессах мышления, как если бы они были алгоритмичными. Компьютеры подобны разуму во многих отношениях; они могут хранить данные, запоминать их, манипулировать ими, научиться распознавать новые схемы и даже создавать новые когнитивные схемы. Мыслительная деятельность человека подобна действиям компьютеров; люди могут манипулировать цепочками символов в соответствии с правилами языка и математики» (МАККормАК 1990: 367-368).

Компьютер, программы представлены в языковом сознании как существа сознательные, поскольку эти слова могут сочетаться с глаголами желания: «Компьютер не хочет видеть фотоаппарат» (http://useroff.com/); «Если ваш компьютер не хочет включаться и вместо обычного звукового сигнала выдает череду непонятных звуков, значит что-то не так и надо разбираться где проблема» (http://imtera.ru); «Что делать, если компьютер хочет загрузиться, но не может» (http://vindavoz.ru) и др. глаголами, предполагающими сознательные, контролируемые действия: «Сервер предоставил сертификат, выданный организацией, которую операционная система компьютера не считает надежной. Это может означать, что сервер создал свой собственный сертификат, которому Google Chrome не может доверять, или что вмешался злоумышленник» (http://www.cyberforum.ru); «Переодически запрашивает проверку при загрузке страницы, или совсем отказывается выполнять запрос. Ни стационарник, ни ноутбук, ни телефон не обменивались файлами последние 3 недели» (http://virusinfo.info). Заметим, что в примерах компьютер не хочет включаться, компьютер не хочет загрузиться парадоксально совмещаются метафора живого существа и метафора механизма: живое существо не включается, включается механизм, вместе с тем механизм не может желать, у него не может быть собственной воли - им управляют, а он осуществляет определенные функции.

Метафоре живого существа соответствует и глагол ругаться, также используемый иногда по отношению к компьютеру: «Комп ругается, что диск С забит» (http://www.cyberforum.ru), «Компьютер ругается на светодиодные габариты» (http://www.w203club.com), «Не открывается Гугл. Ругается, что

\footnotetext{
2 Под термином компьютерная метафора, как правило, понимается «метафора, построенная на сравнении мозга и разума человека с компьютером» (ЖЕРЕБило 2010).
} 
с моего компьютера поступают автоматические запросы» (http://virusinfo.info), «Google Chrome и Opera ругаются на автоматические запросы компьютера» (http://virusinfo.info), «компьютер нового пользователя ругается» (http://www. sql.ru/forum), «Браузеры на компьютере ругаются на сертификат безопасности: „Сертификат безопасности сайта не является доверенным!“» (http://forum. kaspersky.com).

\section{5. Взаимодействие метафор}

Описанные выше метафоры не просто структурируют наше представление о компьютере и всем том, что с ним связано, но, как уже упоминалось, могут и взаимодействовать друг с другом в пределах одного высказывания/ текста. Рассмотрим более подробно следующий текст из «Большой компьютерной энциклопедии»:

«Антивирусная программа - компьютерная программа, предназначенная для поиска вирусов, диагностики, профилактики вирусного заражения компьютера и устранения последствия такого заражения. Компьютерный вирус это программа, которая обладает способностью к саморазмножению (самостоятельному копированию), дописывая себя к коду других программ, и может выполнять на компьютере нежелательные действия. Антивирус анализирует код проверяемой программы на предмет наличия в ней нежелательного «дописанного» кода и в большей части случаев может удалить тело вируса из программы, не нарушив ее дальнейшей работоспособности. Так работает антивирусный сканер. Другой модуль, антивирусный монитор, проводит проверку «на лету», анализируя всю дисковую и сетевую активность компьютера и выявляя подозрительные файлы на носителях и процессы в памяти. Также некоторые современные антивирусы комплектуются модулем обнаружения и удаления программ-шпионов (Spyware), которые могуm, например, передавать данные о владельце компьютера, отслеживать нажатия клавиш и т. д.» (ДуБЕНЮК 2007: 16).

Вирус, диагностика, профилактика, вирусное заражение, саморазмножение вируса - все это задает «медицинскую» метафору, обусловленную метафорой живого существа. По данным МАС, диагностика - «раздел медицины, изучающий признаки болезней, методы и принципы установления диагноза»; «установление диагноза» (MAC), и именно так диагностика представлена в обыденном языковом сознании (существует еще техническая диагностика, но в толковых словарях это значение не отражается). Профилактика может относиться и к медицинской метафоре, и к метафоре механизма, так как слово имеет два значения: 1. «совокупность мероприятий в медицине по укреплению здоровья, предупреждению и устранению причин заболеваний» и 2. «совокупность технических мероприятий, предохраняющих что-л. от преждевременной порчи, износа и т. П. Профилактика и ремонт автомобилей». Метафора механизма поддерживается в анализируемом контексте также единицами модуль и комплектуются. 
Поиск, как отмечалось, поддерживает метафору пространства.

Может выполнять, могут передавать, может удалить - предполагают субъект - живое существо (странно и неестественно было бы сказать чайник может кипятить воду). До появления компьютеров, искусственного интеллекта, анализировать, дописывать, проводить проверку, выявлять, обнаруживать, отслеживать могли только существа, обладающие разумом. Эта же метафора поддерживается и словом подозрительный: оно обладает валентностью на субъект подозрения - существо, обладающее сознанием.

\section{6. Выводы}

На основании предпринятого анализа компьютерной лексики можно констатировать, что на бытовом, т. е. достаточном для непрофессионального пользования компьютером, уровне русский язык успешно освоил новую область. Более того, лексический пласт языка, обслуживающий эту сферу, настолько широк, что становится возможным говорить не о единичных метафорах, а о целых системах метафор, по-разному отражающих в нашем сознании представление о компьютере и всем, что с ним связано. Это структурные метафоры в терминологии Дж. Лакоффа и М. Джонсона, понимаемые как метафорические понятия, при которых «один концепт метафорически структурирован в терминах другого» (ЛАкофФ-Джонсон 2008: 35).

Несомненный интерес представляют семантические модификации, которые претерпела лексика обыденного языка с ее применением к компьютерной сфере. Для организации пользовательского интерфейса были взяты слова обыденного языка и им было приписано новое значение в рамках понятийного поля. Однако внимания заслуживают не только те лексемы, которые всплывают на экране в процессе работы («общения») с компьютером, но и те лексемы, которые употребляют пользователи, когда они говорят о компьютере. Внутренняя форма рассматриваемых лексем формирует восприятие компьютера и Интернета как рядовыми пользователями, так и специалистами, что позволяет говорить о языковом образе компьютера и Интернета в русском языковом сознании.

\section{Словари и энциклопедии}

ДуьЕНЮк 2007 = ДуБЕНЮК Н. (ред.) Больщая компьютерная энциклопедия. Москва: «Эксмо», 2007.

ЖЕРЕБИЛО 2010 = ЖЕРЕБИЛО Т. В. Словарь лингвистических терминов. Назрань: «Пилигрим», 2010.

МАС = ЕвГЕНьеВА А. П. (ред.) Словарь русского языка. Т. 1-4. Москва: «Полиграфресурсы», «Русский язык», 1999.

Ривкин $2010=$ Ривкин В. Л. Медицинский толковый словарь. Москва: «Медпрактика$\mathrm{M»,} 2010$. 


\section{Литература}

АВЕРБУХ И Др. 2007 = АВЕРБУХ В. Л., БАЙДАЛИН А. Ю., БАХТЕРЕВ М. О., ИСМАГИЛОВ Д. Р., ТрушенковА П. В. Структуры компьютерных метафор. В кн.: Труды Института математики и механики Уро РАН. Т. 13. №2. 1-39.

АВЕРБУХ и др. 2008 = АВЕРБУХ В. Л., БАЙДАЛИН А. Ю., ИСМАГИЛОВ Д. Р., КАЗАНЦЕВ А. Ю. Трехмерные методики визуализации программного обеспечения параллельных и распределенных вычислений. В кн.: Параллельные вычислительные технологии (ПаВТ' 2008). Труды международной научной конференции (Санкт-Петербург, 28 января - 1 февраля 2008 г.). Челябинск: «Издательство ЮурГУ», 2008. 283-288.

ГАЛКИНА $2004=$ ГАлКИНА О. В. Метафора как инструмент познания (на материале терминов-метафор компьютерного интерфейса). Дис. канд. фил. наук. Тверь, 2004.

ИСМАГИЛОВ-ШАРПАН 2003 = ИСМАГИЛОВ Д. Р., ШАРПАН С. В. Метафора комнатЫ. Примеры разработки систем компьютерной визуализации. В кн.: Проблемы теоретической и прикладной математики. Труды XXXIV Региональной молодежной конференции. Екатеринбург: «ИММ УрО РАН», 2003. 264-268.

КоляСЕВА $2009=$ КоляСЕВА А. Ф. Нормализация компьютерной терминологии и обыденное метаязыковое сознание специалистов компьютерной сферы. В кн.: Слово. Грамматика. Речь. Вып. 11. Москва, 2009. 19-27.

ЛАКОФФ-ДжОНСОН 2008 = ЛАКОФФ Дж., ДжОНСон М. Mетафоры, которыми мы живем. Москва: «ЛКИ», 2008.

ЛЕйБов 1997 = ЛЕйБОВ Р. Язык рисует Интернет. Internet №4. http://www.gagin.ru/ internet $/ 4 / 9 . \mathrm{html}$.

ЛожкинА 2001 = ЛожкинА Е. Р. Социально-психологические аспекты междисциплинарного подхода к проектированию современного компьютерного интерфейса. Дис. канд. псих. наук. Ярославль, 2001.

МАККОРМАК $1990=$ МАККОРМАК Э. Когнитивная теория метафоры. В кн.: АРУТЮНОВА Н. Д. (сост.) Теория метафорыл. Москва: «Прогресс», 1990. 358-387.

РЕПкин 1999-2009 = РеПкин Д. Виртуальная реальность. http://www.virtual.ru/virtual reality.html.

Эко 1998 = Эко У. От Интернета к Гутенбергу: текст и гипертекст. [Лекция Умберто Эко на экономическом факультете МГУ, 20 мая 1998 г.] http://philosophy.ru/ library/eco/internet.html.

Barbosa-Souza $2000=$ Barbosa S. D. J., DE Souza C. S. Extending software through metaphors and metonymies. In: Proceedings of the 5th International Conference on Intelligent User Interfaces. New Orleans, Louisiana, 2000. 13-20.

Barr-Noble-Biddle 2004 = Barr P., Noble J., Biddle R. A Semiotic Model of UserInterface Metaphor. In: Liu Kecheng (ed.): Virtual, Distributed and Flexible Organisations. Boston: Kluwer Academic Publishers, 2004. 189-215.

JoHnSON $1994=$ JoHnSON G. J. Of Metaphor and the Difficulty of Computer Discourse. Communication of the ACM 1994/12: 97-102.

MCCARThy 1979 = MCCARThy J. Ascribing mental qualities to machines. In: Ringle M. (ed.) Philosophical Perspectives in Artificial Intelligence. Atlantic Highlands, New Jersey: Humanities Press, 1979. 161-195. 